\title{
Changes in fish habitat on the Missouri River from Fort Peck Dam to the North Dakota state line: 1956-2009
}

\author{
Prepared for: \\ Montana Fish, Wildlife, and Parks \\ Region 6 Fisheries \\ Prepared by: \\ Sara Owen and Jamul Hahn \\ Montana Natural Heritage Program \\ a cooperative program of the \\ Montana State Library and the University of Montana
}

February 2014

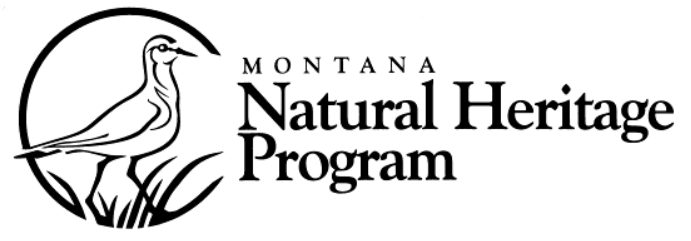




\section{Changes in fish habitat on the Missouri River from Fort Peck Dam to the North Dakota state line: 1956-2009}

Prepared for:

Montana Fish, Wildlife, and Parks

Region 6 Fisheries

Agreement Number:

140010

Prepared by:

Sara Owen and Jamul Hahn
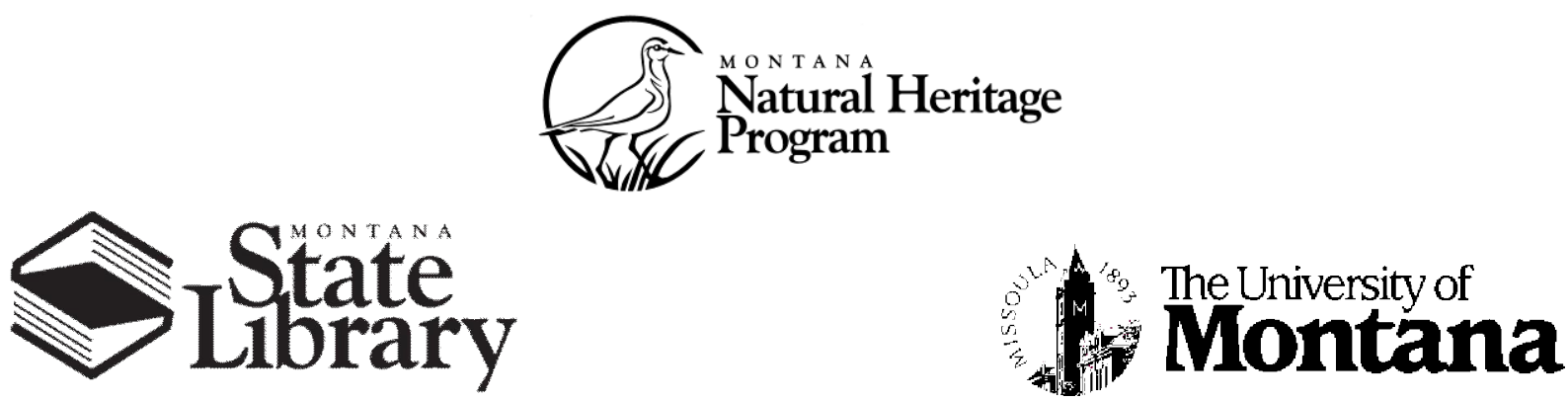

C2014 Montana Natural Heritage Program

P.O. Box 201800 ǒ 1515 East Sixth Avenue ǒ Helena, MT 59620-1800 ǒ 406-444-5354 
This document should be cited as follows:

Owen, Sara and Jamul Hahn. 2014. Changes in fish habitat on the Missouri River from Fort Peck Dam to the North Dakota state line: 1956-2009. Report to Montana Fish, Wildlife, and Parks. Montana Natural Heritage Program, Helena, Montana. 22 pp. 


\begin{abstract}
Off-channel habitats such as backwaters and side channels provide important nursery and feeding habitats for native fishes of the Missouri River, including the endangered pallid sturgeon (Scaphirhynchus albus). We mapped backwaters, side channels, and secondary channels (henceforth referred to as ñther channelsò) on the Missouri River between Fort Peck dam and the North Dakota state line for 1956/57, 2009, and 2011, the latter of which was a flood year. We compared the total number of mapped features and mean length, area, and perimeter of the features between 1956/57 and 2009. Each habitat type increased significantly in total number between 1956/57 and 2009. Although we observed an increase in the total number of offchannel habitats between 1956/57 and 2009, the average area of each type of habitat decreased by $50 \%$, which suggests that these areas may be unsuitable for the pallid sturgeon and other native fishes of the Missouri River below Fort Peck dam. A large flood event in 2011 may have been a significant enough event to restore these habitats; examination of post-flood imagery may help answer that question and guide restoration and recovery efforts for the pallid sturgeon.
\end{abstract}




\section{ACKNOWLEDGMENTS}

This project was funded by the Montana Fish, Wildlife, and Parks. We would like to thank Andy Brummond in the FWP Lewistown Area Resource Office for his invaluable support and guidance during this process. Karen Newlon and Linda Vance of MTNHP provided useful comments on an earlier draft of this report. Any errors or omissions in the report are entirely the responsibility of the authors. 


\section{TABLE OF CONTENTS}

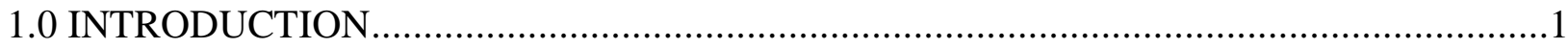

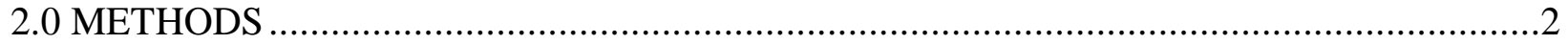

2.1 Study Area

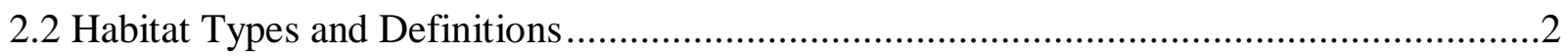

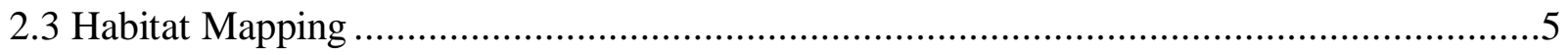

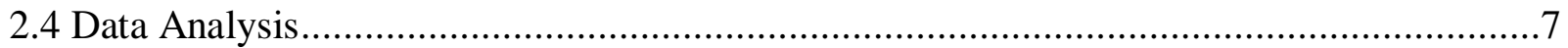

3.0 RESULTS

4.0 DISCUSSION

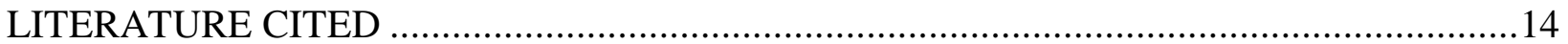




\section{LIST OF TABLES}

Table 1. Historic changes in the number, area, length, and perimeter of off-channel aquatic habitats in the study area

Table 2. Relative changes in the number, length, area, and perimeter of habitat features in the study area.

\section{LIST OF FIGURES}

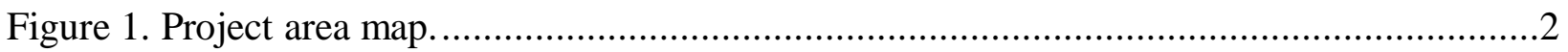

Figure 2. Example of a backwater habitat .....................................................................

Figure 3. Example of a side channel habitat..................................................................

Figure 4. Example of an other channel habitat............................................................

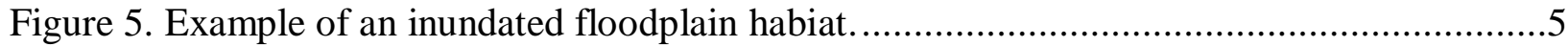

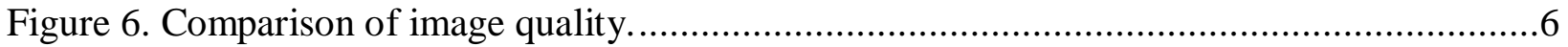

Figure 7. Differences in water levels between images....................................................

Figure 8. Proportion of habitat features in 1956/57 and 2009........................................10

Figure 9. Changes in off-channel aquatic habitat features............................................ 12

Figure 10. Changes in off-channel aquatic habitat features after flooding. ............................13 


\subsection{INTRODUCTION}

Dams constructed for hydroelectric power and flood management disconnect large floodplain rivers from their floodplains (Bayley 1995, Shields, Jr. et al. 2000, Yager et al. 2013), altering the flow of water and sediment through the reduction of high peak flows, resulting in channel simplification (Ligon et al. 1995). Overbank flows and channel avulsions that occur during flood events are key components in the maintenance of abandoned channels, backwaters, oxbow lakes, and other off-channel habitats (Shields, Jr. et al. 2000). Some off-channel habitats, like abandoned channels and oxbow lakes, may be connected to the main river channel only during flooding. Others, like backwaters and side channels, remain connected to the main channel during base flows and serve as habitat for fish and other aquatic fauna throughout the year. These off-channel habitats are characterized by shallow, slow moving water, higher water temperatures than the main channel, and silt-dominated substrates (Sheaffer and Nickum 1986). High flows are necessary for both channel migration and the transport of sediments that maintain these habitats (Dryer and Sandvol 1993, Ward and Stanford 1995). The reduction or elimination of dynamic river processes by river stabilization structures such as dams can result in the loss of these key habitats as sedimentation rates outpace scouring and channel migration events (Shields, Jr. et al. 2000, Yager et al. 2013).

Backwaters and side channels provide important shallow water spawning and nursery habitats to the native fishes of the Missouri River downstream of Fort Peck dam (Dryer and Sandvol 1993), including the pallid sturgeon (Scaphirhynchus albus), which has been listed as endangered under the Endangered Species Act since 1990 (Bramblett and White 2001). These habitats provide important benefits to aquatic ecosystems such as spawning and nursery grounds for fish (Whitley and Campbell 1974, Sheaffer and Nickum 1986, Sedell et al. 1990, Yager et al. 2011), refuge from predators and high river velocities, particularly during flood events (Sedell 1990, Yager et al. 2013), and increased macroinvertebrate production and density compared to the main river channel (Whitley and Campell 1974, Shaeffer and Nickum 1986, Yager et al. 2013). In addition, backwater habitats may have an abundance of woody debris that provides important foraging and spawning sites (Ward and Stanford 1995, Lehtinen et al. 1997).

This study is modeled after Yager et al. (2013) who examined changes in backwater and side channel habitats on the Missouri River in South Dakota. The objective of this study was to determine if the relative quantity of side channel and backwater habitats on 298 kilometers (185 miles) of the Missouri River downstream of Fort Peck dam has changed significantly between 1956/57 and 2009. The results will provide valuable insight in directing pallid sturgeon recovery efforts and native fish management along with the related operations of Fort Peck dam. Additionally, backwater and side channel habitats were quantified for summer 2011, which was a record high flow year (USACE), to provide direction of future work to determine instream flow levels necessary for pallid sturgeon recovery efforts and native fish management of the Missouri River. 


\subsection{METHODS}

\subsection{Study Area}

The project study area encompassed approximately 298 kilometers of the Missouri River between Fort Peck dam and the North Dakota state line (Figure 1). Fort Peck dam, completed in 1937, was the first of six main stem dams built on the Missouri River by the 1960s (Yager et al. 2013). The Pallid Sturgeon Recovery Plan (Dryer and Sandvol 1993) identifies this segment of the Missouri River as one of six recovery-priority management areas based on recent records of pallid sturgeon occurrence and the probability that these areas still provide suitable habitat for pallid sturgeon. The recovery-priority areas are viewed as the most suitable segments of river to employ restoration and recovery efforts because they are typically the least degraded and have the highest habitat diversity.

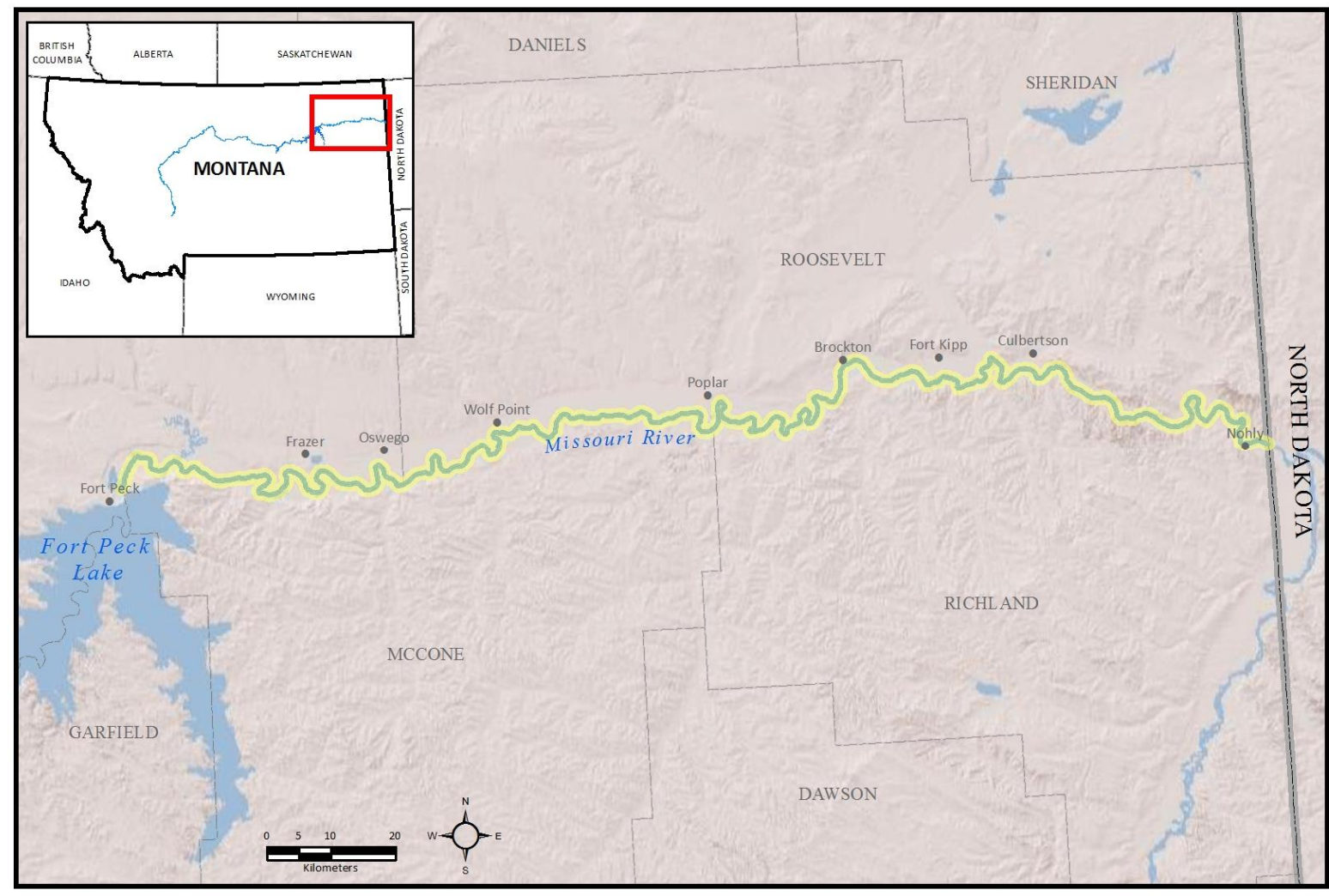

Figure 1. The project area includes the Missouri River from below Fort Peck dam downstream to the North Dakota state line.

\subsection{Habitat Types and Definitions}

We identified and delineated four habitat types: backwaters, side channels, other channels, and inundated floodplain. The inundated floodplain category was used only for the 2011 analysis. Although backwaters and side channels are fairly restricted in their definitions, this project used 
slightly modified definitions to best meet the objectives of this study. Each habitat type is defined and illustrated below.

\section{Backwaters}

Backwaters were typically defined as bodies of water with only a downstream connection to the main river channel and no upstream connection during baseline flows (Yager et al. 2013; Figure 2). In a handful of cases, bodies of water with an upstream connection but no downstream connection (i.e., ñdead endò channels) were also classified as backwaters for lack of a better category for placement. Backwaters are typically mapped on the outside shore of a river channel; however, for this project we also mapped backwaters on islands (including sandy, midchannel bars), as pallid sturgeon have been documented using habitat near islands (Bramblett and White 2001). The island backwater habitats were tagged so that they can be pulled out and analyzed separately in the future if desired.

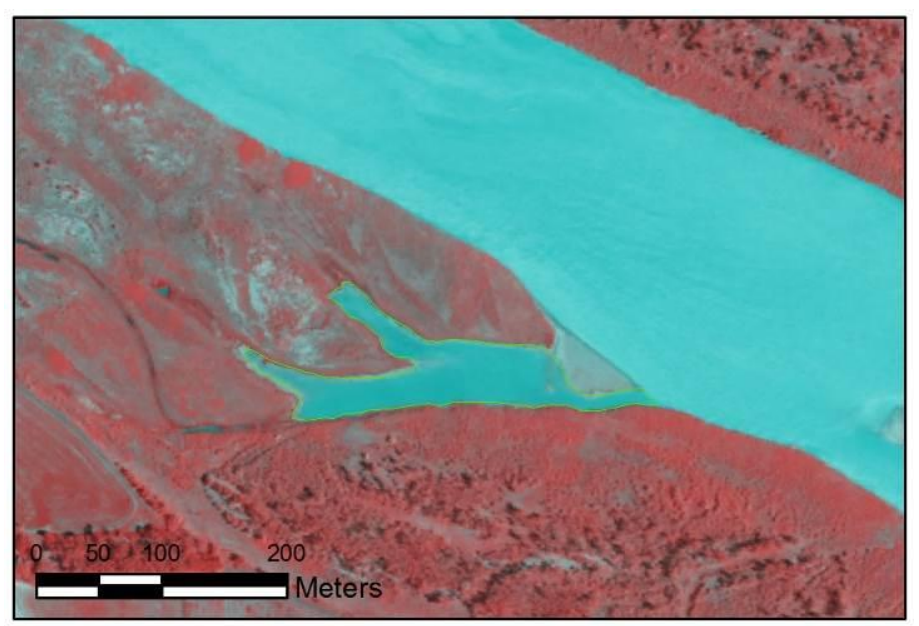

Figure 2. A representative backwater channel of the Missouri River mapped for this project.

\section{Side Channels}

Side channels were defined as flowing off-channel habitats with both an upstream and downstream connection to the main river channel. Yager et al. (2013) defined side channels as features less than $100 \mathrm{~m}$ wide. For the purposes of this study, side channels were typically restricted to $30 \mathrm{~m}$ wide or less (Figure 3 ). This allowed us to use approximately the same proportion of side channel to main channel width as Yager et al (2013). 


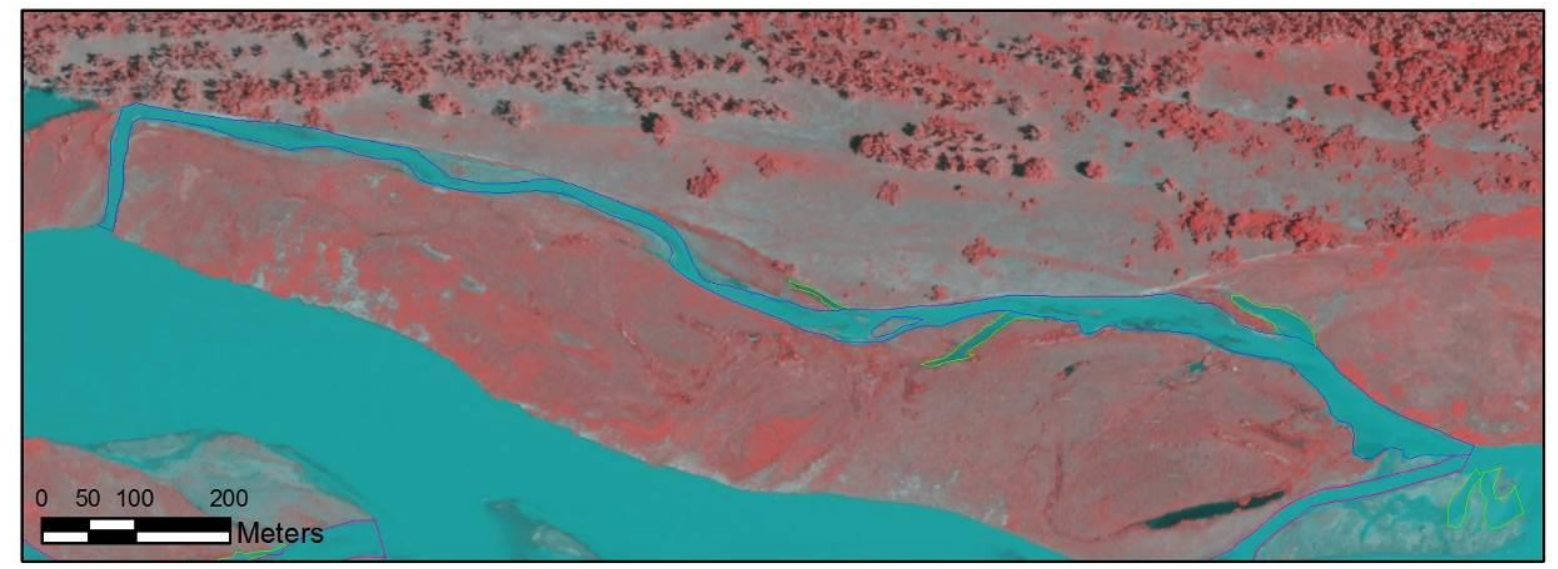

Figure 3. A typical side channel was long and narrow, less than $30 \mathrm{~m}$ wide.

\section{Other Channels}

In addition to the habitats mapped in Yager et al. (2013), we also mapped other channels that encompassed sinuous channel areas with subclimax seral-stage islands and/or mid-channel bars (Figure 4). Bramblett and White (2001) found pallid sturgeon used these habitats extensively.

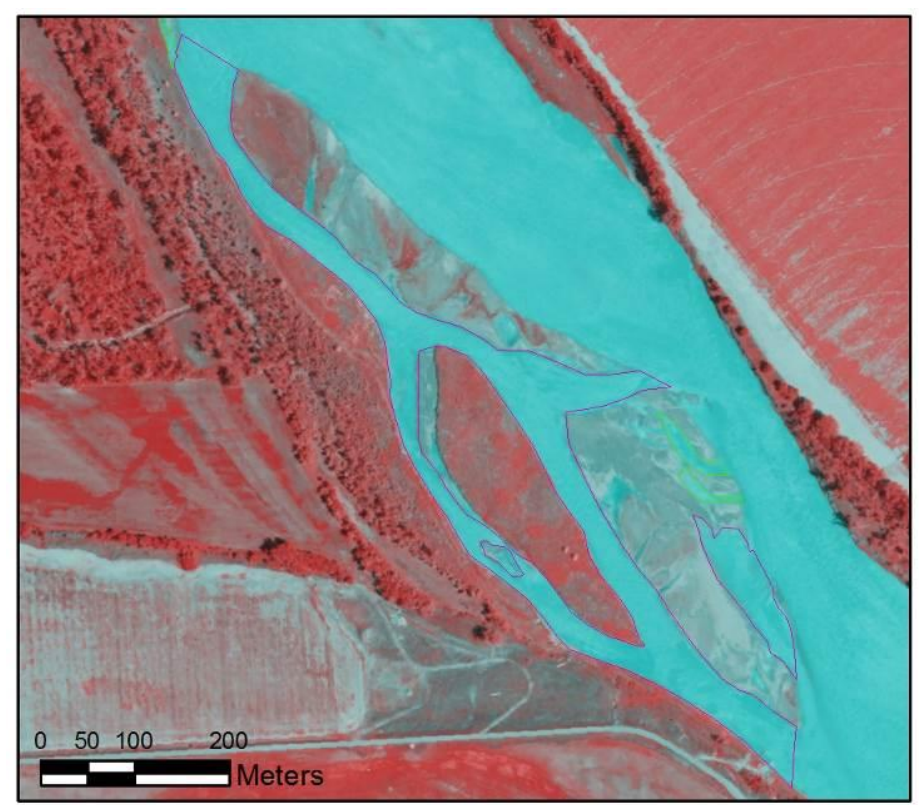

Figure 4. Other channels are secondary channels that are wider than 30 m but do not carry a majority of river flow.

\section{Inundated Floodplain}

We mapped inundated floodplain habitat for 2011 only and identified this habitat as areas where the river overtopped its banks and inundated the riparian floodplain. We included both forested and non-forested habitat. The inundated floodplain category was added to encompass flooded areas that are potential habitat and refugia for fish and other aquatic fauna during flood events 
(Ligon et al. 1995, Ward and Stanford 1995, Bunn and Arthington 2002). The edges of the inundated floodplains along the river channel were delineated using the 2009 imagery because they were flooded and not visible in the 2011 imagery.
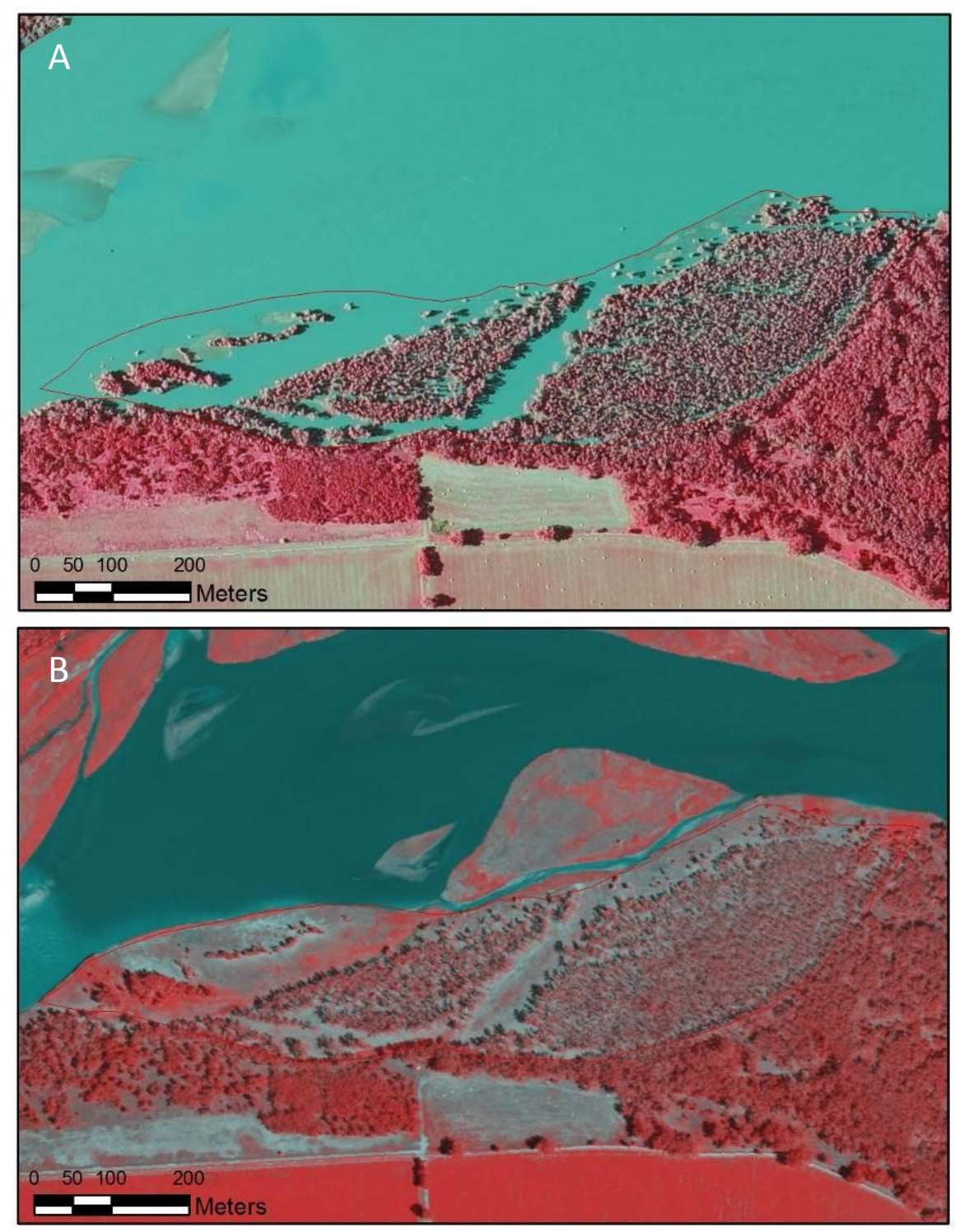

Figure 5. The inundated floodplain category was used only for 2011 imagery (A), but the 2009 imagery was used to delineate the floodplain (B).

\subsection{Habitat Mapping}

Aquatic habitats were mapped to 1956/57 black and white imagery (U.S. Department of Agriculture) and 2009 and 2011 color-infrared imagery (National Agricultural Imagery Program). The 2009 imagery was flown between 7/11-7/23/2009 and the 2011 imagery was flown between 7/15-7/25/2011. The 2009 and 2011 imagery have a pixel resolution of $1 \mathrm{~m}$. The 
historic imagery (1956/57) was obtained from the Aerial Photography Field Office as scanned images. The historic imagery was flown between 8/1-11/26/1956 and 6/23-9/26/1957 and has a pixel resolution of $0.25 \mathrm{~m}$. The spatial location of the historical photography was georeferenced with ESRI® ArcMap 10.0 software. Each image was orthorectified and aligned to the Montana 2009 NAIP imagery and projected into the NAD 83 Montana State Plane coordinate system. A first-order polynomial transformation using three control points was used to link and align the historical photography with the spatially referenced 2009 NAIP imagery. Control points used include street and road intersections, bridge locations, rock outcrops, corners of established fields, building corners and, occasionally, large cottonwood trees.

All recognizable off-channel habitats (backwaters, side channels, other channels, and inundated floodplains) were interpreted as described above and digitized as polygon features in a geodatabase using ArcMap 10.0. We mapped all features at a scale of 1:4,000. We calculated the area, length, and perimeter of each off-channel habitat feature in ArcMap. In cases where water was shallow over sand, it was difficult to determine if there was a connection to the main channel, and we tended to map conservatively for these questionable areas. These instances were particularly common in the historical imagery. The image quality varied between images and between years, so to improve delineation of habitats, we used overlapping images where available (Figure 6).
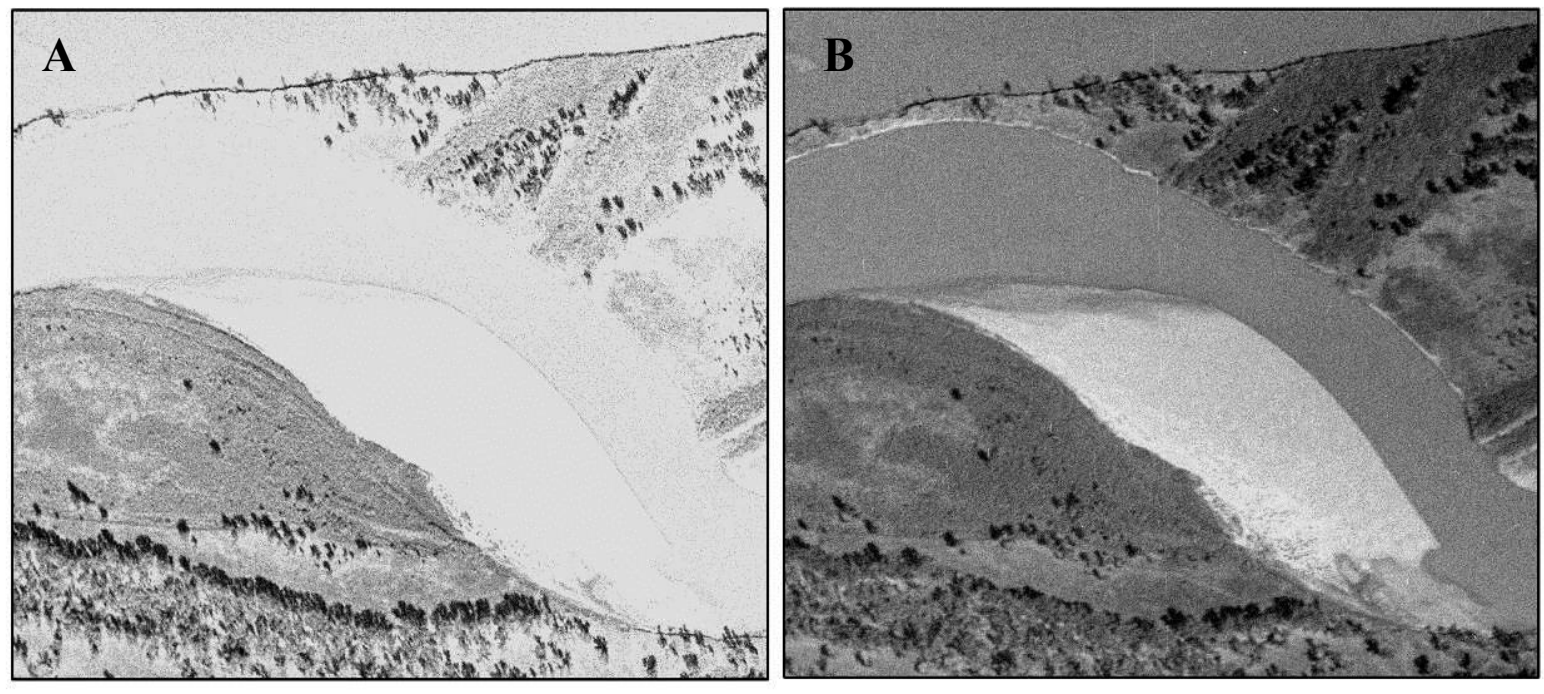

Figure 6. Image quality varied between images, making delineation of off-channel habitat features difficult (A). There was usually enough overlap between images that one of better contrast could be used to identify and delineate habitat features.

The historical imagery provided additional challenges in mapping the aquatic habitat features. The water levels were different between some images because the imagery was flown over two years and over a period of several months within the same year. It was common to see a feature in one image, but where another image overlapped, the water level was higher and the feature did not exist. In these cases, every effort was made to map the feature to the image that had lower 
water (Figure 7). Additionally, due to the orthorectification process, a historical image was more ñueò to location in the western half of the image, and tended to drift away from its true location further east in the image. The difference in distance between features was usually no more than $75 \mathrm{~m}$. Every effort was made to map features in the western half of the image in order to maintain a more exact geographic location. Usually there was enough overlap between images to allow for this technique; however, there were a few cases where a feature extending across two images did not line up spatially. To preserve the true shape and area of the feature, the feature was mapped as a single polygon in one image, and then mapped as a separate polygon in the other image. The second polygon was moved to line up with the first polygon, and the two were merged into a single feature.
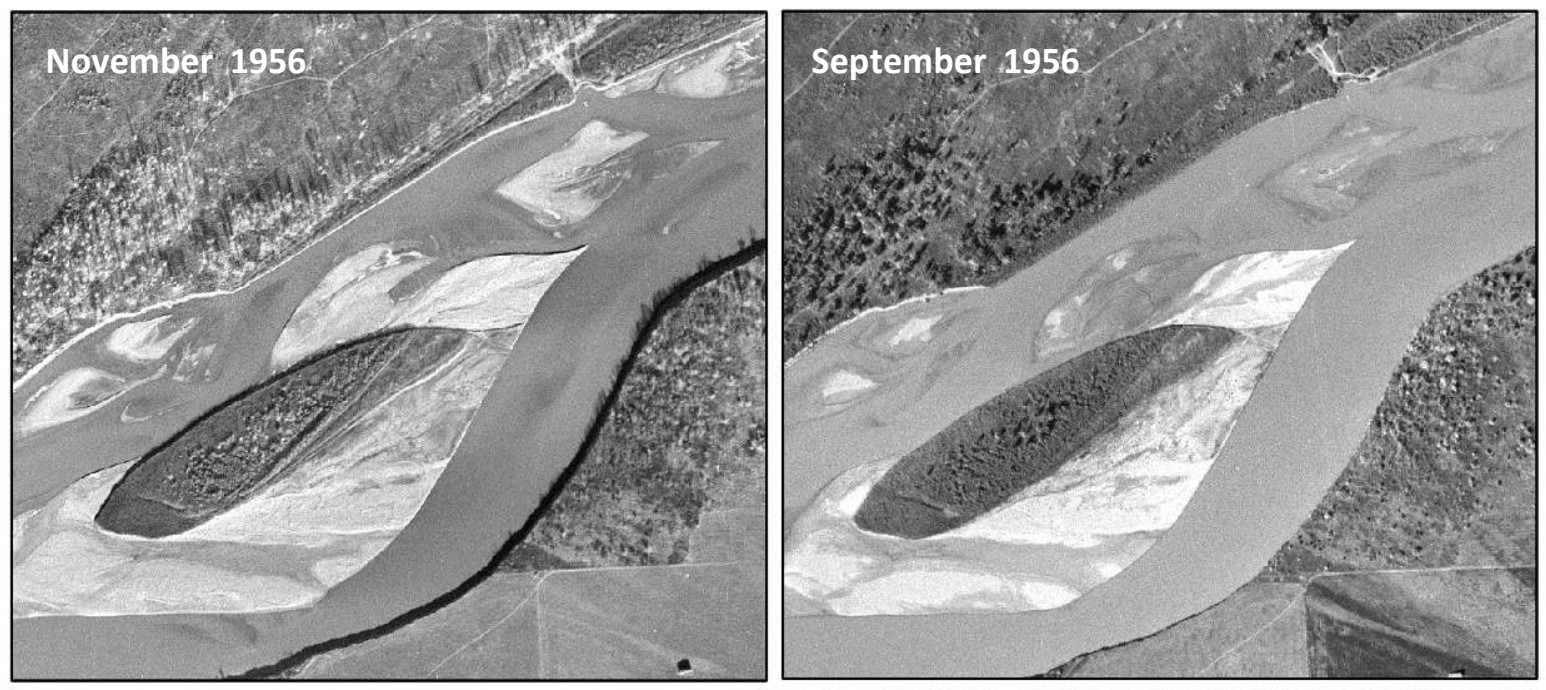

Figure 7. The dates of the historical imagery spanned two years and more than one season within the same year. In some cases the water levels differed between overlapping images. Offchannel features were mapped to the lower water image when possible.

\subsection{Data Analysis}

We tested for significant differences in mean characteristics of the off-channel habitats (area, perimeter, and length) between the 1956/57 and 2009 image years using a t-test with unequal variances. We also calculated mean area, length, and perimeter for each habitat type in 2011. The chi-squared test for independence was used to assess changes in the relative numbers of backwaters, side channels, and other channels between the 1956/57 and 2009 image years. All calculations were done in Microsoft Excel ${ }^{\circledR}$ Analysis ToolPak (Microsoft Corporation, Redmond, Washington). For all statistical tests, p-values Oे.05 were considered statistically significant. 


\subsection{RESULTS}

Although the number of each habitat type (backwaters, side channels, and other channels) was higher in 2009 than in 1956/57, the mean area, length, and perimeter of each habitat feature were less in 2009 (Table 1). The mean area of all habitat features was 50\% less in the 2009 imagery, despite an $82 \%$ increase in the number of total mapped habitat features (Table 2). This trend followed for average length and average perimeter of all habitat features, which saw declines of $31 \%$ and $28 \%$, respectively. The total area of all mapped features declined slightly (-9\%), but the total area of side channels increased by $35 \%$ (Table 2). This corresponded with a substantial increase in the number of side channel features mapped in 2009 compared to 1956/57 (105 vs. 29). Total perimeter of all mapped features was $24 \%$ greater in 2009 than in $1956 / 57$ and total length of all features was $20 \%$ greater in 2009 than in 1956/57. This was due, in part, to an increase in total perimeter and total length of both side channels and other channels (Table 2).

We observed a shift in the relative and absolute number of mapped habitat features between the two image years. We observed an increase in the total number of each type of habitat feature in 2009 (Table 1), but the proportion of habitats changed significantly between 1956/57 and 2009 $\left(G^{2}=27.39\right.$, d.f. $\left.=2, \mathrm{p}<0.001\right)$. In $1956 / 57$, twenty years after Fort Peck dam was completed, backwaters made up 66\% of all mapped features. In 2009 backwaters made up 53\% of mapped features. Over the same time period, side channels increased in proportion from 5\% to $11 \%$ of mapped features, and other channels increased from $28 \%$ to $36 \%$ of all mapped habitat features (Figure 8).

Despite an increase in the total area of side channels, the average area of side channels decreased significantly between $1956 / 57$ and $2009(-63 \%, \mathrm{p}=0.002)$. The mean area of other channels also decreased significantly over this time period $(-64 \%, \mathrm{p}<0.001)$. Mean backwater area, though smaller in 2009 than in 1956/57, was not significantly different $(-40 \%, \mathrm{p}=0.13)$. Mean perimeter and mean length differed significantly between years for all habitat features (Table 1). In both image years, there was at least one off-channel habitat feature that was substantially larger than all other mapped features. These features were a backwater (2009 only) associated with a channel meander cutoff and an other channels feature that was mapped immediately below Fort Peck dam (1956/57 and 2009).

Habitat features mapped in 2011 were vastly different than the other years, and for that reason, were not compared to previous yearsômapping. We mapped 449 total habitat features for 2011: 195 backwater features, 15 side channel features, 92 other channel features, and 147 inundated floodplain features (Table 1). The mean area for all mapped habitat features in 2011 was larger than those features in 2009 (Table 1). The number of side channels mapped in 2011 declined markedly from 2009. In general, mapped side channels in 2009 were flooded in 2011 and were mapped as other channels due to their size. In total, we mapped 3,611.29 ha of habitat features in 2011 compared to 756.29 ha in 2009 and 834.24 ha in 1956/57. 
Table 1. The number, length, area, and perimeter of off-channel aquatic habitats mapped from Fort Peck dam downstream to the North Dakota state line from 1956/1957, 2009, and 2011 aerial imagery.

\begin{tabular}{|c|c|c|c|c|c|c|c|c|}
\hline $\begin{array}{l}\text { Imagery } \\
\text { Date }\end{array}$ & $\begin{array}{c}\text { Feature } \\
\text { Type }\end{array}$ & $\begin{array}{c}\text { Total } \\
\text { Number }\end{array}$ & $\begin{array}{c}\text { Total Length } \\
(\mathrm{m})\end{array}$ & $\begin{array}{c}\text { Mean Length } \\
(\mathrm{m})\end{array}$ & $\begin{array}{c}\text { Total Area } \\
\text { (ha) }\end{array}$ & $\begin{array}{c}\text { Mean Area } \\
\text { (ha) }\end{array}$ & $\begin{array}{c}\text { Total Perimeter } \\
(\mathrm{m})\end{array}$ & $\begin{array}{c}\text { Mean } \\
\text { Perimeter }(\mathrm{m})\end{array}$ \\
\hline \multirow[t]{4}{*}{$1956 / 1957$} & Backwater & 347 & $69,156.64$ & $199.30(11.68)^{* *}$ & 166.28 & $0.48(0.05)$ & $160,736.74$ & $463.22(28.90)^{* *}$ \\
\hline & Side channel & 29 & $29,962.89$ & $1,033.20(123.47)^{*}$ & 103.16 & $3.56(0.64)^{* *}$ & $74,452.19$ & $2,567.32(340.17)^{* *}$ \\
\hline & Other channel & 149 & $97,775.14$ & $656.21(51.62)^{* *}$ & 564.81 & $3.79(0.62)^{*}$ & $247,545.65$ & $1,661.38(141.04)^{* *}$ \\
\hline & ALL FEATURES & 525 & $196,894.67$ & 375.04 (21.11) & 834.24 & $1.59(0.19)$ & $482,734.59$ & 919.49 (56.10) \\
\hline \multirow[t]{4}{*}{2009} & Backwater & 506 & $58,954.81$ & $116.51(6.13)^{* *}$ & 145.03 & $0.29(0.12)$ & $146,923.91$ & $290.36(29.11)^{* *}$ \\
\hline & Side channel & 105 & $65,465.90$ & $623.48(41.78)^{*}$ & 139.57 & $1.33(0.13)^{* *}$ & $163,434.44$ & $1,556.52(108.43)^{* *}$ \\
\hline & Other channel & 345 & $121,825.25$ & $353.12(19.48)^{* *}$ & 471.69 & $1.37(0.18)^{*}$ & $324,607.36$ & $940.89(57.02)^{* *}$ \\
\hline & ALL FEATURES & 956 & $246,245.96$ & 257.58 (10.52) & 756.29 & $0.79(0.09)$ & $634,965.71$ & $664.19(31.60)$ \\
\hline \multirow[t]{5}{*}{2011} & Backwater & 195 & $73,243.41$ & $375.61(33.38)$ & 466.88 & $2.39(0.97)$ & $215,662.97$ & 1,105.96 (134.46) \\
\hline & Side channel & 15 & $10,076.87$ & 671.79 (93.31) & 20.37 & $1.36(0.27)$ & $23,373.83$ & $1,558.26(220.80)$ \\
\hline & Other channel & 92 & $52,532.75$ & $571.01(67.47)$ & 473.75 & $5.15(1.76)$ & $147,366.34$ & $1,601.81(242.08)$ \\
\hline & Inundated floodplain & 147 & $159,091.82$ & $1,082.26(66.67)$ & $2,650.29$ & $18.03(2.53)$ & $538,344.45$ & 3,662.21 (295.39) \\
\hline & ALL FEATURES & 449 & $294,944.85$ & 656.89 (33.09) & $3,611.29$ & $8.04(1.05)$ & $924,747.59$ & 2,059.57 (134.44) \\
\hline
\end{tabular}

For means, standard errors are reported in parentheses.

* P-values less than 0.005

** P-values less than 0.001 
Table 2. Relative changes in the number, length, area, and perimeter of habitat features between 1956/57 and 2009 from Fort Peck dam downstream to the North Dakota state line.

\begin{tabular}{l|ccccccc} 
& $\begin{array}{c}\text { Number } \\
\text { of } \\
\text { Features }\end{array}$ & $\begin{array}{c}\text { Total } \\
\text { Length }\end{array}$ & $\begin{array}{c}\text { Mean } \\
\text { Length }\end{array}$ & $\begin{array}{c}\text { Total } \\
\text { Area }\end{array}$ & $\begin{array}{c}\text { Mean } \\
\text { Area }\end{array}$ & $\begin{array}{c}\text { Total } \\
\text { Perimeter }\end{array}$ & $\begin{array}{c}\text { Mean } \\
\text { Perimeter }\end{array}$ \\
\hline Backwater & $46 \%$ & $-15 \%$ & $-42 \%$ & $-13 \%$ & $-40 \%$ & $-9 \%$ & $-37 \%$ \\
Side Channel & $262 \%$ & $54 \%$ & $-40 \%$ & $35 \%$ & $-63 \%$ & $54 \%$ & $-39 \%$ \\
Other Channel & $63 \%$ & $20 \%$ & $-46 \%$ & $-16 \%$ & $-64 \%$ & $24 \%$ & $-43 \%$ \\
TOTAL FEATURES & $82 \%$ & $20 \%$ & $-31 \%$ & $-9 \%$ & $-50 \%$ & $24 \%$ & $-28 \%$
\end{tabular}

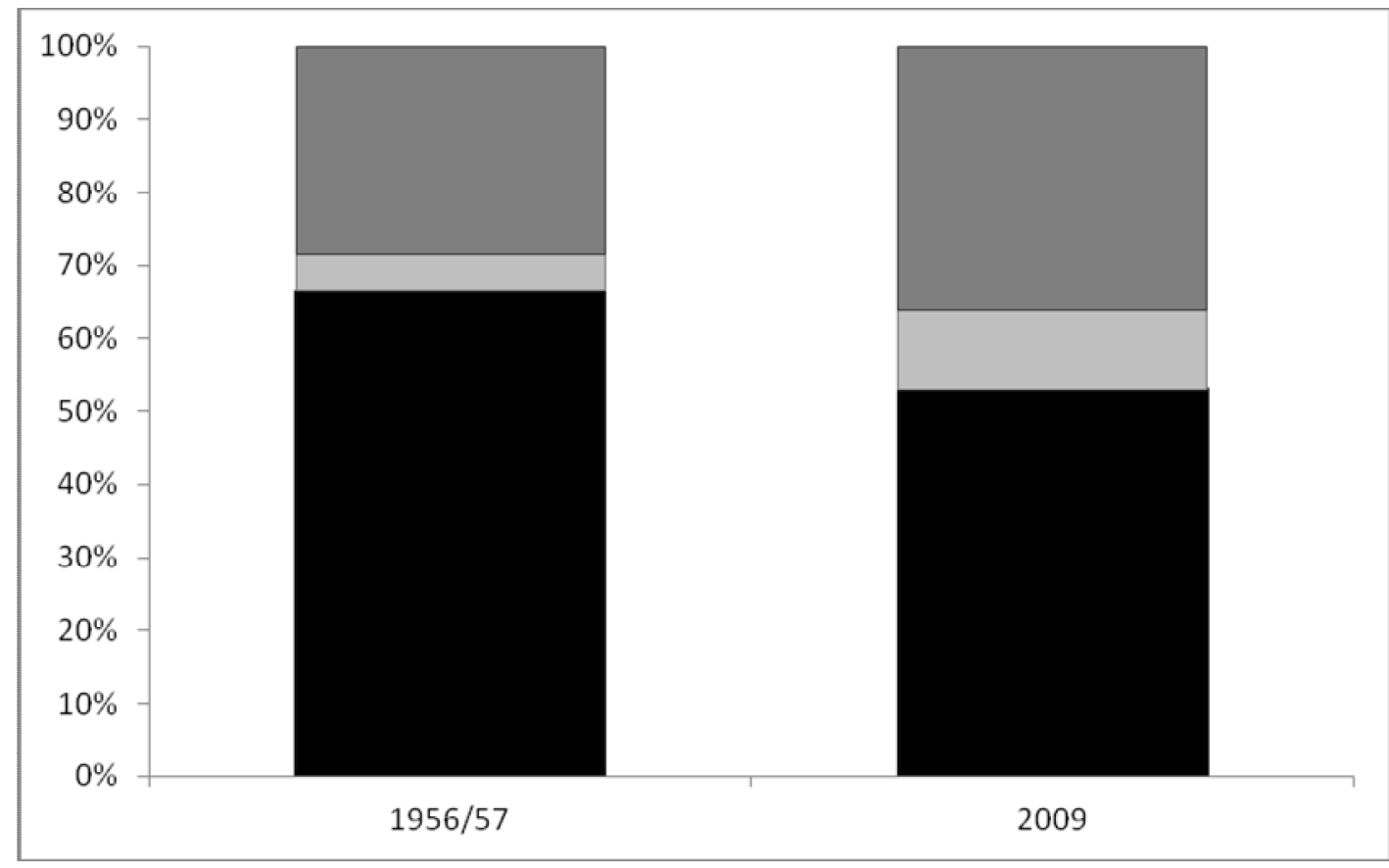

Figure 8. Proportion of habitat features mapped from Fort Peck dam downstream to the North Dakota state line from aerial imagery in 1956/57 and 2009. Black bars are backwater habitats, light grey bars are side channels and dark grey bars are other channels.

\subsection{DISCUSSION}

Flow regulation of the Missouri River by Fort Peck dam has altered the natural processes of flooding, scouring, and sediment transport along nearly $300 \mathrm{~km}$ of the study area. This has negatively impacted pallid sturgeon populations by reducing habitat, blocking migration routes, and inundating spawning and nursery grounds (Dryer and Sandvol 1993). This study found an increase in the overall number of off-channel habitats that can be used by pallid sturgeon and other native fishes in the Missouri River between 1956/57 and 2009, but a significant decline in 
the area of most of those habitats. The decline in mean area of habitats could be attributed to sedimentation of backwaters and side channels due to a lack of scouring during high flows or channel bed degradation through channel downcutting (Ward and Stanford 1995, Shields, Jr. et al. 2000). Yager et al. (2013) observed declines in total and average length, perimeter, and area of off-channel features, which they attributed to flow regulation and channel bed degradation from two upstream dams. Our observed increase in the numbers of backwaters and side channels may be due to channel degradation (Yager et al. 2013). As peak flows declined after completion of Fort Peck dam, secondary channels may have been converted to narrower, shallower side channels (Figure 9). Similarly, side channels could be converted to backwaters through a loss of upstream channel connection from channel downcutting and sedimentation.

We observed a consistent decrease in average area for each off-channel habitat. This may be a result of sedimentation, which may lead to backwaters and side channels that are too shallow to provide good habitat for pallid sturgeon or other native fish species in this section of the Missouri River. Backwaters and side channels are shallower than the main river channel and have higher water temperatures and productivity that make these habitats high quality nursery grounds for young fish (Sheaffer and Nickum 1986). However, if these habitats become too shallow, water temperatures could potentially rise beyond lethal limits for the fish that use them. Additionally, water that is too shallow may increase the risk of predation from aerial or terrestrial predators, and fish may become trapped and perish in these shallow habitats should they become cut off from the main channel (Ward and Stanford 1995). The decrease in average area for backwaters and other channels from 1956/57 to 2009 may be even more pronounced when taking into account the unusually large mapped features that were associated with channel meander cutoffs. For example, in 2009 the largest backwater feature was 60 ha, nearly 40 times larger than the next largest backwater feature.

We observed an overall increase in the number of habitats mapped the further downstream we moved from Fort Peck dam (Sara Owen, personal observation). This was somewhat expected, given that rivers typically become incised below a dam due to sediment retention above the dam (Ward and Stanford 1995). Unregulated tributaries may mitigate these impacts depending upon their size and distance from the dam. For the section of river in this study, there are few tributaries to the Missouri River, and none are very large. The Milk River is the largest tributary to enter the Missouri River between Fort Peck dam and the confluence with the Yellowstone River. It enters the Missouri River just $15 \mathrm{~km}$ downstream from the dam, so any influence it may have on the river dynamics may be negated due to its close proximity of the dam. Further investigation of the perceived trend of increasing off-channel habitat downstream from the dam may provide helpful information to managers looking for ways to best implement restoration and recovery efforts for the pallid sturgeon.

The record flows of 2011 (USACE) may have reorganized the Missouri River below Fort Peck dam, inundating floodplains, depositing sediments, and scouring new off-channel habitat features (Figure 9). Additional analysis, using the 2013 NAIP, may provide insight into whether the flooding was able to negate some of the impacts of the dam and provide additional off-channel habitats. Bramblett and White (2001) found very few tagged pallid sturgeon in the Missouri River between the confluence of the Yellowstone River and Fort Peck dam, leading them to 


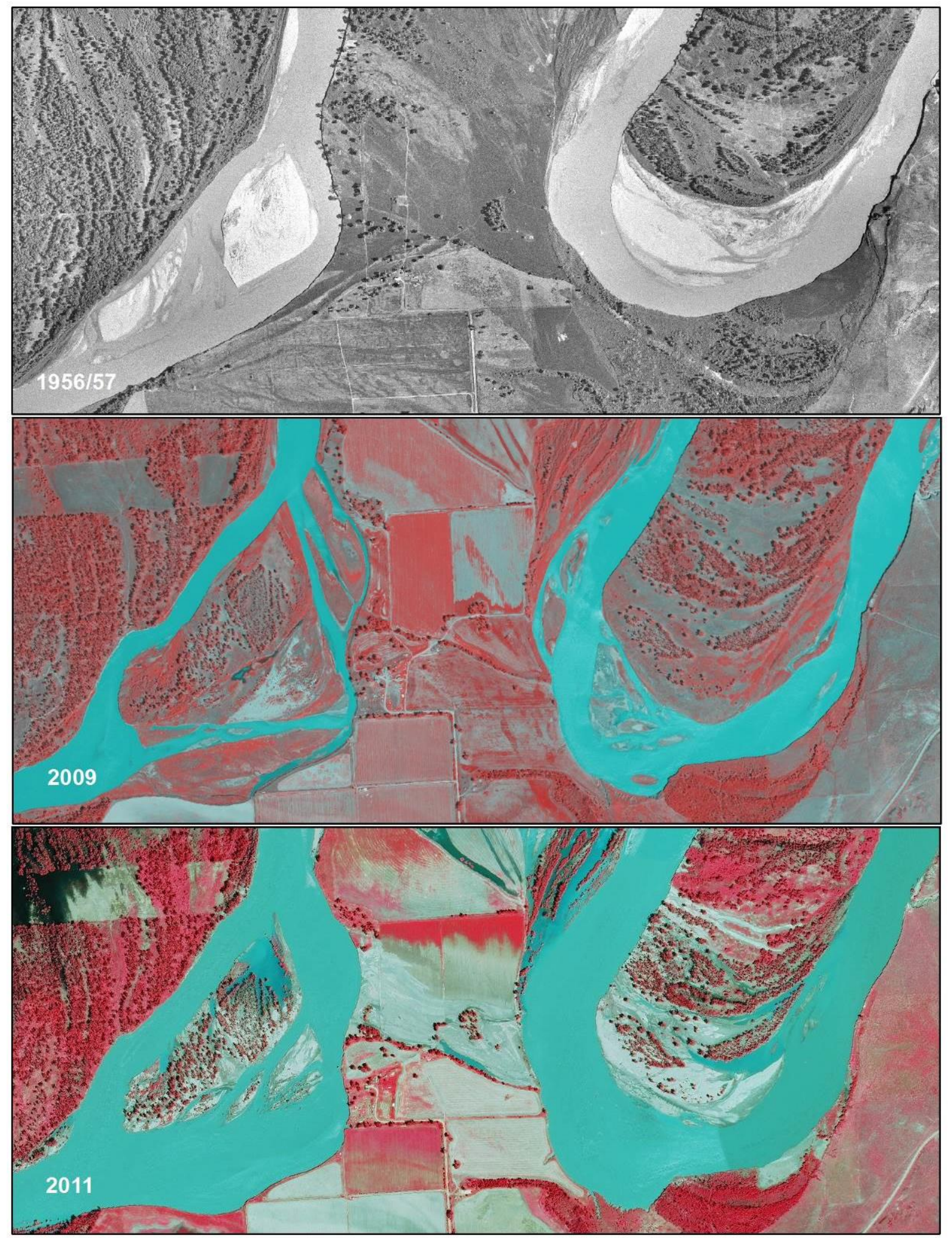

Figure 9. Changes in off-channel aquatic habitat are visible from 1956/57 (top) to 2009 (middle) for part of the study reach. There were additional side channel and backwater features in 2009 that were not present in 1956/57. The flooding of 2011 (bottom) potentially reorganized the channel features again. 
conclude that this particular section of river has less suitable habitat than either the Yellowstone River or the Missouri River between the confluence of the Yellowstone River and Lake Sakakawea in North Dakota. Presumably the impacts of Fort Peck dam reach to the confluence of the Missouri and Yellowstone Rivers.

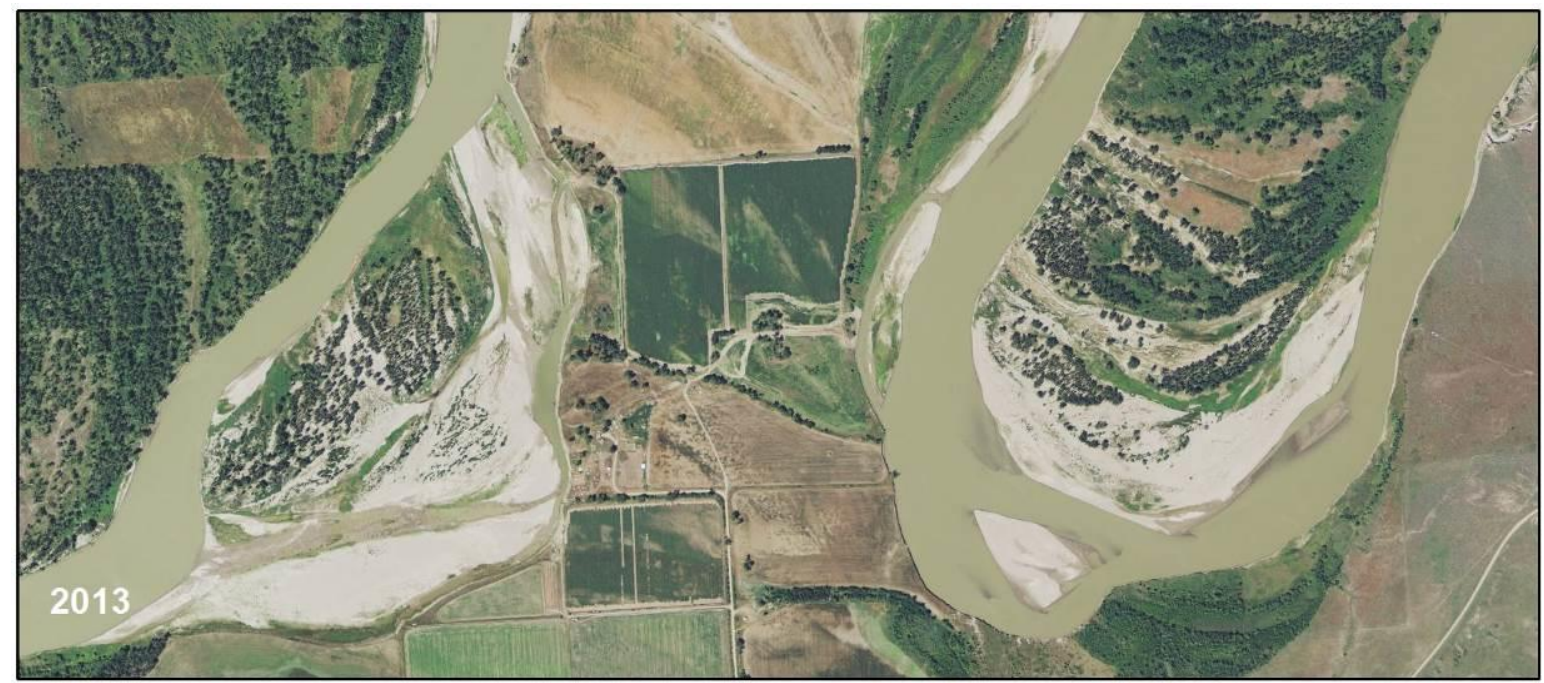

Figure 10. The 2013 imagery of the same area as Figure 9 shows the river channel was reorganized after the 2011 floods. What was a side channel feature in 2009 (left side of image) has been cut off on the upstream end and is now a backwater channel in 2013.

Preservation and, where needed, restoration of off-channel habitats such as backwaters and side channels will be a step in the right direction for assuring desired aquatic habitat for all of the Missouri Riverôs native fish species, not just the pallid sturgeon. Sheaffer and Nickum (1986) found that backwaters of the Mississippi River served as nursery habitats for 13 fish families, and that nearly half of the fish caught in their study were from the family Cyprinidae. Two species of cyprinids, the sturgeon chub (Macrhybopsis gelida) and sicklefin chub (M. meeki) are species of concern in the state of Montana that are found in the Missouri River (MTNHP 2013). Gerrity et al. (2006) found that nearly $80 \%$ of the diet of juvenile pallid sturgeon was comprised of sturgeon chub and sicklefin chub, although macroinvertebrates are also an important prey item (Wanner et al. 2007). Wanner et al. (2007) suggested the decline in the number of native cyprinids in the Missouri River may partially explain the decline in the pallid sturgeon. Thus, an important step in the restoration and recovery efforts for the pallid sturgeon would be to focus on off-channel habitats like backwaters and side channels that provide habitat not only for the pallid sturgeon, but also for other native species as well. 


\section{LITERATURE CITED}

Bayley, P.B. 1995. Understanding large river-floodplain ecosystems. Bioscience 45(3): 153158.

Bramblett, R.G. and R.G. White. 2001. Habitat use and movements of pallid and shovelnose sturgeon in the Yellowstone and Missouri Rivers in Montana and North Dakota. Transactions of the American Fisheries Society 130: 1006-1025.

Bunn, S.E. and A.H. Arthington. 2002. Basic principles and ecological consequences of altered flow regimes for aquatic biodiversity. Environmental Management 30 (4): 492-507.

U.S. Fish and Wildlife Service. 1993. Pallid sturgeon recovery plan. U.S. Fish and Wildlife Service, Bismarck, North Dakota. 55pp.

Gerrity, P.C., C.S. Guy, and W.M. Gardner. 2006. Juvenile pallid sturgeon are piscivorous: a call for conserving native cyprinids. Transactions of the American Fisheries Society 135: 604-609.

Lehtinen, R.M., N.D. Mundahl, and J.C. Madejczyk. 1997. Autumn use of woody snags by fishes in backwater and channel border habitats of a large river. Environmental Biology of Fishes 49: 7-19.

Ligon, F.K., W.E. Dietrich, and W.J. Trush. 1995. Downstream ecological effects of dams. Bioscience 45(3): 183-192.

Montana Natural Heritage Program (MTNHP). 2013. Animal Species of Concern. Retrieved February 5, 2014 from http://mtnhp.org/SpeciesOfConcern/?AorP=a.

Sedell, J.R., G.H. Reeves, F.R. Hauer, J.A. Stanford, and C.P. Hawkins. 1990. Role of refugia in recovery from disturbances: modern fragmented and disconnected river systems. Environmental Management 14(5): 711-724.

Sheaffer, W.A. and J.G. Nickum. 1986. Backwater areas as nursery habitats for fishes in Pool 13 of the Upper Mississippi River. Hydrobiologia 136: 131-140.

Shields, F.D. Jr., A. Simon, and L.J. Steffen. 2000. Reservoir effects on downstream river channel migration. Environmental Conservation 27(1): 54-66.

U.S. Army Corps of Engineers (USACE). Fort Peck Project Statistics. U.S. Army Corps of Engineers, Omaha District website. Retrieved February 5, 2014 from www.nwo.usace.army.mil/Media/FactSheets.aspx.

Wanner, G.A., D.A. Shuman, and D.W. Willis. 2007. Food habits of juvenile pallid sturgeon and adult shovelnose sturgeon in the Missouri River downstream of Fort Randall dam, South Dakota. Journal of Freshwater Ecology 22 (1): 81-92. 
Ward, J.V. and J.A. Stanford. 1995. Ecological connectivity in alluvial river ecosystems and its disruption by flow regulation. Regulated Rivers: Research and Management 11: 105119.

Whitley, J.R. and R.S. Campbell. 1974. Some aspects of water quality and biology of the Missouri River. Transactions, Missouri Academy of Science 7/8: 60-72.

Yager, L.A., M.D. Dixon, T.C. Cowman, and D.A. Soluk. 2013. Historic changes (1941-2008) in side channel and backwater habitats on an unchannelized reach of the Missouri River. River Research and Applications 29(4): 493-501. 